\title{
The effect of pasture species on lamb performance in dryland systems
}

\author{
T.J. FRASER ${ }^{1}$, R.A. MOSS $^{2}$, M.J. DALY ${ }^{1}$ and T.L. KNIGHT ${ }^{1}$ \\ ${ }^{1}$ AgResearch, PO Box 60, Lincoln \\ ${ }^{2}$ AgResearch, Winchmore Research Station, Private Bag 803, Ashburton
}

\begin{abstract}
The effects of two contrasting forage supply options on forage and sheep production were evaluated on unirrigated farmlet systems at Winchmore, Mid-Canterbury. One option was based on perennial ryegrass pastures (Control), and the other (Improved) on hybrid ryegrass, tall fescue, and chicory pastures. All pasture types grew at similar low rates during winter but chicory grew more rapidly than the grasses during the summer droughts. The Control conserved more but required less conserved feed than the Improved system. Both had a feed deficit which averaged 23 and $42 \mathrm{~kg}$ $\mathrm{DM} /$ ewe respectively over the 2 years. The lambs on the Improved pastures grew more rapidly than the Controls throughout, exceeding the rate of the Controls by 142 and $165 \mathrm{~g} /$ head/day post-weaning in years 1 and 2 respectively. This resulted in considerably more lambs reaching target drafting weights on the Improved system, 92 vs. 53 and 97 vs. $58 \%$, in years 1 and 2 respectively. This increased the income from lambs by $\$ 104$ and $\$ 94 /$ ha in these years. Ewe liveweights were similar during pregnancy but differed during lactation and post-weaning at the end of which, ewes on Improved pastures were 6 and $4 \mathrm{~kg}$ heavier than the Controls in years 1 and 2 respectively. They consequently produced fleeces that were 10 and $12 \%$ heavier. The superior animal performance associated with the Improved system reflects higher pasture quality due to less endophyte and dead matter, and an increase in the proportion of the more nutritious components, legumes and chicory.
\end{abstract}

Keywords: dryland, lamb production, pasture production, pasture quality, pasture species

\section{Introduction}

The sheep industry has identified improved lamb growth rates as the highest priority for sheep forage research. This would increase the capacity of farmers to respond to changing market specifications for timing of supply and/or carcass weight. Higher lamb growth rates could also improve the quality of the lamb that New Zealand supplies to the European Christmas market by allowing more farms to supply new season spring lambs. Compared with lambs overwintered from the previous year, new season spring lambs have improved meat tenderness, flavour and overall acceptability (Devine et al. 1993).

The experiment reported in this paper is the first part of a study designed with the objective of (1) comparing forage and animal production in experimental farmlet systems based on different forages, (2) modifying existing computer simulation models so that they are able to accurately represent the experimental systems, and (3) using computer simulation to extrapolate and interpolate to other supply and forage utilisation options.

A systems approach was used to allow interactions to occur and be measured. The experiment was designed to detect within-year interactions for both forage performance and sheep performance, and between year interactions for forage performance. Pasture renewal, included in forage treatments, affected forage supply and system costs. Interactions between forage type and reproductive performance of sheep were not expected and the experimental design minimised such effects. The systems approach means that (1) system costs and returns were recorded to permit economic analysis; (2) livestock performance was recorded with the number of lambs meeting the predefined carcass criteria each year used for system comparison; (3) pasture performance was recorded to assist in explaining how the treatments affected livestock and economic performance: seasonal forage supply and quality patterns were expected to differ between forage treatments; (4) numerous system measurements were required to allow systematic management of the experimental systems (e.g., insect pest populations to trigger insecticide use).

\section{Methods}

The experiment was located at the Winchmore Research Station in Mid-Canterbury, on a Lismore stony silt loam soil. The establishment of the experiment started in 1996 and measurements started with farmlet stocking in February 1997.

The experimental design involved six farmlets (two forage supply systems each with three replicates). Each 
farmlet consisted of 12 permanent paddocks, with temporary sub-division available when required. The average paddock size was 0.37 ha, and total farmlet size 4.44 ha.

Forage supply in the experiment was designed on a systems basis, recognising that pastures require renewal to maintain forage quality and productivity, with the higher quality pasture types requiring more frequent renewal than perennial ryegrass pastures. As a result, systems had pastures of various age and productivity at the start of the experiment and pasture renewal occurred every year in both systems.

One forage supply option (Control) was based on perennial ryegrass (Lolium perenne) pastures, and the other (Improved) on a mixture of high quality pastures. The Improved forage supply option was designed to maximise lamb growth rates, but could also have effects on ewe liveweight and wool production. Improved farmlets contained three basic pastures: hybrid ryegrass (L. $x$ boucheanum syn L. hybridum), tall fescue (Festuca arundinacea), and chicory (Chicorium intybus). The cultivars used were selected to optimise animal performance.

The number of paddocks of each pasture type in Improved farmlets was based on a study which took into account livestock feed demand patterns, pasture growth patterns, nutritive value of different pasture types, sward persistence and reductions in pasture growth associated with pasture renewal. A linear programme was used to select the optimum paddock combination for the Improved treatment. Pasture renewal was expected to be more frequent in Improved treatments than in Control treatments, but the costs of pasture renewal were not considered in the choice of forage combinations. The Control treatment had all 12 paddocks in high endophyte ryegrass pasture while the Improved treatment had five in nil endophyte hybrid ryegrass and chicory pasture, three in fescue and four in chicory and red clover (Trifolium pratense). All pastures except chicory were sown with white clover (Trifolium repens).

Rainfall was measured daily at a NIWA meteorological station sited at Winchmore Research Station. Soil moisture was measured weekly on the long-term irrigation trial at Winchmore using a Time Domain Reflectometry meter. Agricultural drought days (where the soil moisture is at or below $10 \%$ ) were calculated (Rickard 1960).

\section{Pasture management}

With continual pasture renewal planned for all pasture types, a range of pasture age was required at the start of the experiment in 1997. For the Control treatments, paddocks with a range of pasture age (1-6 years) were selected for the experiment. For the Improved farmlets, new pastures were established on nine of the 12 paddocks in the spring of 1996. Three additional paddocks were established in each Improved farmlet in February 1997.

Within each farmlet, and within each forage type, one Improved and two Control paddocks were selected for renewal each year. Selection was based on both pasture production in the previous year and invasion of weeds. Selection was made independently within each farmlet each year. In the Improved pastures, chicory replaced tall fescue, tall fescue followed ryegrass, and ryegrass followed chicory. This rotation minimises carry-over of diseases in chicory. Ryegrass and fescue pastures were direct drilled during autumn after a summer fallow using the double spray technique (Fraser \& Hewson 1994). Chicory was spring sown into a cultivated seedbed.

Pasture conservation and topping were carried out as required to maintain feed quality. At the start of lambing each year it was planned to have a minimum pasture cover of $1000 \mathrm{~kg} \mathrm{DM} / \mathrm{ha}$.

All paddocks were soil tested (100 mm soil depth) annually during June, with samples taken from permanent $100 \mathrm{~m}$ transects. Analysis included: $\mathrm{pH}$, Olsen $\mathrm{P}, \mathrm{K}$, sulphate $\mathrm{S}$ and organic $\mathrm{S}, \mathrm{Ca}, \mathrm{Mg}$ and $\mathrm{Na}$. Fertiliser was applied in July with rates calculated to keep minimum soil tests of: pH 5.7, K 7, Olsen P 20, and sulphate $\mathrm{S} 8$. No nitrogen was applied.

Grassgrub (Costelytra zealandica) and porina (Wiseana spp.) populations were monitored but never reached treatment trigger densities.

\section{Animal management}

Mixed age Coopworth ewes, stratified for age and liveweight, were allocated annually to farmlets. With this annual re-allocation, data from different years were treated as independent. Two-tooth ewes were purchased annually for replacements. Mating to Suffolk rams commenced in mid March. Comparable ewe numbers were maintained between treatments continuously, with dead ewes replaced by ewes with a similar liveweight, and if appropriate a similar number of lambs. Three percent and 20 percent of the original ewes were culled during September and November respectively, to simulate annual culling of barrens and annual culls for age.

Differences between Improved and Control farmlets were captured as a difference in the number of lambs meeting the drafting criteria (Table 1), and/or in the amount of supplement being required/conserved.

After the ewes were allocated to treatments (3 weeks pre-mating), they were rotationally grazed with the objective of feeding animals so that weight was 
maintained or increased. This pattern of feeding was maintained until the end of tupping ( 2 cycles). After mating and during winter, ewes were block grazed on a 70 to 100 day rotation with shifts every 2 days, with temporary electric fences positioned to achieve the necessary feed rationing. Ewes and lambs were rotationally grazed from lambing to weaning, after which lambs were rotationally grazed (3-10 day shifts), being offered the best pasture within a farmlet. Ewes were also rotationally grazed, following lambs or cleaning up pastures.

Lambs were weighed at birth with male lambs left entire. They were weaned at a mean age of 11 weeks. Lambs were drafted for slaughter (Table 1) at weaning and every 14 days thereafter until early January. Belowtarget lambs remaining at the last drafting date were removed as "store".

Table 1 Sheep performance targets for a ewes and lambs system on dryland pasture at Winchmore.

\begin{tabular}{lc}
\hline Target & \\
\hline Stocking rate & \\
$\quad$ Ewes wintered per ha & 12.0 \\
Ewe mating & \\
$\quad$ Liveweight (kg) & 60 \\
$\quad$ Start date & mid-March \\
Lamb survival to sale (\%) & 130 \\
Minimum target carcass weight (kg) & \\
$\quad$ Ram lambs & 16.0 \\
$\quad$ Ewe lambs & 14.0 \\
All lambs sold & 1 1 week January \\
Minimum ewe weights & kg/head \\
February & 57 \\
Mating & 60 \\
Start of lambing & 65 \\
Weaning & 55 \\
Shearing & mid-February \\
Wool (kg/SU) & 4.0 \\
\hline
\end{tabular}

The ewes were shorn at the end of the stock year (end of February), to obtain the year's wool production, but in the first year they were also shorn pre-lambing.

Internal parasite status was assessed by faecal worm egg counts (FEC). For ewes, these were done one month before lambing, one month after lambing commenced (lambed ewes) and one month before mating. Lambs were sampled at weaning then at 2-weekly intervals. Copper and cobalt status was assessed from liver samples obtained at slaughter using the OPTIGROW service. Urine from ewes was tested for Zearalenone 2 weeks before and 1 week after joining the ram.

\section{Pasture measurements}

Potential growth from the four pasture types and overall growth from each system was quantified. This required two different techniques. Growth was measured on 13 selected paddocks using a standardised regime; 4 paddocks, of different ages, in the Control ryegrass and three paddocks of each of the three Improved pastures. The double trim technique as described by Lynch (1960) was used. There were two $1.5 \mathrm{~m}$ by $2.5 \mathrm{~m}$ measurement cages per paddock. Cuts were taken at monthly intervals using a rotary mower cutting $25 \mathrm{~mm}$ above ground level.

Pasture mass was measured monthly on each paddock using visual assessment with calibration cuts. Separate assessment and calibration cuts were done for each pasture type. Sixteen quadrats $\left(0.25 \mathrm{~m}^{2}\right)$ of pasture were selected to represent the range of pasture mass present in the pasture type to be assessed. Each quadrat was visually assessed before paddock assessments commenced. In each paddock 20 visual pasture mass estimates were recorded from a quadrat $\left(0.25 \mathrm{~m}^{2}\right)$ placed in pasture. The quadrat reference areas were harvested by cutting herbage to ground level with a shearing handpiece. The resulting sample was washed to remove extraneous material. Data from the reference areas were used to fit calibration equations (quadratic), and the mean pasture mass of each paddock calculated.

Herbage botanical and chemical composition was measured to determine herbage quality during critical feed quality periods, at flushing, lambing, and weaning. Representative paddocks were sampled. Samples were separated into the following components: dead herbage, legume, grass leaf, grass stem, chicory leaf, chicory stem and weeds.

Hay and silage made, and the amount fed, was assessed from bale number, bale weight and dry matter percentage. Barley grain supplementation was weighed daily.

\section{Animal measurements}

All sheep were recorded individually and liveweights measured from unfasted animals, weighed within 1 hour of removal from pasture. Reproductive performance of ewes was recorded at parturition when the ewe tag number was recorded, lambs tagged, weighed, and sex, birth and rearing rank recorded. Lambs were weighed at 4 and 8 weeks of age, at weaning (11 weeks), then at 14-day intervals until the final draft. Ewes were weighed when allocated to treatments, then monthly until lambing, then when lambs were at 4 and 8 weeks of age, at lamb weaning and then monthly.

Wool was bulked for sheep within farmlets, then weighed.

Lambs were sent for slaughter (Table 1) in farmlet mobs and carcass weight, financial values, grade and GR (fat depth) from each farmlet were recorded from 
the freezing works return sheets. The weight of lambs sold as stores and their value was recorded. The age at drafting was calculated for those reaching target weights, by averaging the number of days between birth and drafting (Table 8).

\section{Results and discussion}

\section{Climate}

Years 1 and 2 followed similar climatic trends with lower than normal spring and summer rainfalls (Table 2). The high number of summer drought days (70 and 87) compared to the long-term mean of 33 , is particularly relevant to its impact on lamb performances.

Table 2 Rainfall and number of agricultural drought days at Winchmore.

\begin{tabular}{lrrrrr}
\hline & autumn & winter & spring & summer & $\begin{array}{c}12-\text { month } \\
\text { total }\end{array}$ \\
\hline Rainfall $(\mathrm{mm})$ & & & & & \\
$1997 / 98$ & 215 & 157 & 127 & 119 & 618 \\
$1998 / 99$ & 147 & 152 & 115 & 114 & 528 \\
49 yr mean & 197 & 186 & 172 & 179 & 734 \\
Drought days & & & & & \\
$1997 / 98$ & 2 & 0 & 8 & 70 & 80 \\
$1998 / 99$ & 12 & 0 & 19 & 87 & 118 \\
47 yr mean & 9 & 0 & 6 & 33 & 48 \\
\hline
\end{tabular}

\section{Pasture and animal health}

Grassgrub and porina numbers, animal internal parasites, lamb copper and cobalt levels and ewe zearalone levels were always low, requiring no remedial treatment. There were no differences between systems.

\section{Pasture performance}

Herbage growth rates were similar for the three grass species used on the two systems (Table 3 ) and all species grew at similar low rates during winter. However, chicory grew more rapidly during the summer droughts than the grasses.

Pasture cover was higher on the Control than Improved systems throughout each year (Table 4), with the exception of the period immediately after surplus herbage was conserved from the Control system. The lower May covers on the Improved system necessitated the increased input of conserved feed to the Improved system during winter (Table 5). Despite this, covers were still lower than on the Control system at lambing during August. Covers on the Control increased further during spring relative to those on the Improved system resulting in considerably higher quantities being conserved on the Control system.

While the Control system had higher amounts of cover, its quality was considerably lower than that available on the Improved systems (Table 6). This difference was especially pertinent to the effects on lamb liveweight performance during late spring and early summer (Table 7).

During November in both years, the herbage offered to the Control lambs contained more dead matter and less clover than occurred on the Improved system (Table 6). Lambs on the Improved system had swards available containing in excess of $50 \%$ clover and chicory.

There was more herbage conserved but less required on the Control than the Improved system (Table 5). The majority of conserved feed requirements occurred during the autumn of year 2 following a summer drought, which resulted in a feed supply deficit equating to 54 and $78 \mathrm{~kg} \mathrm{DM} /$ ewe on the Control and Improved systems in that year.

\section{Animal performance}

Liveweight performance of the lambs on the Improved system (Table 7), both pre- and post-weaning, was significantly better than the Controls. At pre-weaning

Table 3 Mean pasture growth rate 1997-99 (DM kg/ha/day) on dryland pasture at Winchmore.

\begin{tabular}{|c|c|c|c|c|}
\hline & $\begin{array}{c}\text { Control } \\
\text { ryegrass }\end{array}$ & ryegrass & $\begin{array}{l}\text { Improved -- } \\
\text { tall fescue }\end{array}$ & chicory \\
\hline March and April 97 & 20 & 29 & 24 & 23 \\
\hline $\begin{array}{l}\text { May to August } 97 \\
\text { September to }\end{array}$ & 6 & 10 & 8 & 5 \\
\hline $\begin{array}{l}\text { November } 97 \\
\text { December } 97 \text { to }\end{array}$ & 36 & 43 & 44 & 48 \\
\hline February 98 & 5 & 9 & 5 & 20 \\
\hline March and April 98 & 20 & 19 & 20 & 20 \\
\hline $\begin{array}{l}\text { May to August } 98 \\
\text { September to }\end{array}$ & 8 & 10 & 8 & 7 \\
\hline $\begin{array}{l}\text { November } 98 \\
\text { December } 98 \text { to }\end{array}$ & 37 & 50 & 42 & 46 \\
\hline February 99 & 9 & 21 & 8 & 25 \\
\hline
\end{tabular}

Table 4 Pasture cover at strategic feeding periods (DM kg/ha) in two dryland systems under sheep grazing at Winchmore.

\begin{tabular}{|c|c|c|c|c|c|c|c|}
\hline & May 1997 & August 1997 & November 1997 & May 1998 & August 1998 & November 1998 & April 1999 \\
\hline Control & 2290 & 1710 & 2620 & 2440 & 2030 & 3260 & 2690 \\
\hline Improved & 2010 & 1460 & 2730 & 1930 & 1530 & 2280 & 2590 \\
\hline Significance ${ }^{1}$ & ns & $*$ & ns & * & * & * & ns \\
\hline
\end{tabular}

${ }^{1} \mathrm{~ns}=$ not significant, ${ }^{*}=\mathrm{P}<0.05$ 
this was an increase of 16 and $23 \mathrm{~g} /$ head/day in years 1 and 2 respectively but this superiority increased to 142 and $165 \mathrm{~g} / \mathrm{head} /$ day postweaning.

This increased liveweight performance from the Improved groups resulted in considerably more lambs reaching target drafting liveweights, 92 vs. 53 and 97 vs. $58 \%$, in years 1 and 2 respectively (Table 8 ). Carcass weights averaged 15.5 vs. 15.0 and $15.1 \mathrm{vs} .14 .9 \mathrm{~kg}$ for years 1 and 2 for Improved and Control systems respectively (Table 9). The slightly lower weight from the Controls reflects their lower growth rate. Lambs on the Control systems that reached target weights took 8 days longer to do so in both years than it took those on the Improved system (Table 8).

The increased quantity of dead matter and the lower proportion of the highly nutritious components of the sward (Table 6), clover and chicory, in the Control system would have reduced the sward's palatability, and consequently the animal intake, but these differences also reduced the quality of intake (Fraser \& Rowarth 1996). Hence there was higher herbage cover (Table 4) and lower lamb liveweight performances (Table 7) on the Control compared to the Improved systems. The increase in lamb growth rate of the Improved system lambs resulted in a 12 and $16 \%$ increase in total meat produced per ha in years 1 and 2 . The increased number and improved marketability of the heavier lambs, increased the income from lambs by $\$ 104$ and $\$ 94 /$ ha in years 1 and 2 (Table 9).

Treatment effects on ewe liveweights were negligible until lactation and postweaning when weights of the Improved ewes increased relative to the Controls (Table 10). They were $6 \mathrm{~kg}(\mathrm{P}<0.05)$ and $4 \mathrm{~kg}$ (ns) heavier during mid-February at the end of years 1 and 2 respectively. Fleeces from the Improved ewes were 10 and $12 \%$ heavier (Table 11) than Controls when shorn at mid-February during years 1 and 2 respectively and reflected the spring and summer liveweight advantage of the Improved system (Table 10). Ewes were offered a more palatable diet of higher nutritive value and because considerably more lambs were drafted from the Improved system ewes on this system, the ewes had less grazing competition. The combination of these factors resulted in their heavier liveweights and increased wool production. The increased lamb and ewe liveweight performances, despite lower pasture
Table 6 Herbage composition at strategic feeding periods (\% component present) in four pasture mixes in dryland pasture at Winchmore.

\begin{tabular}{|c|c|c|c|c|c|c|}
\hline & \multicolumn{3}{|c|}{$\begin{array}{l}\text {-- Control ryegrass -- } \\
\text { grass clover dead }\end{array}$} & \multicolumn{3}{|c|}{$\begin{array}{c}\text {-- Improved ryegrass -- } \\
\text { grass clover/ dead } \\
\text { chicory }\end{array}$} \\
\hline March 97 & 55 & 8 & 32 & 49 & 4 & 47 \\
\hline November 97 & 58 & 6 & 34 & 69 & 9 & 22 \\
\hline March 98 & 58 & 6 & 34 & 16 & 55 & 15 \\
\hline \multirow[t]{2}{*}{ November 98} & 78 & 7 & 12 & 54 & 16 & 11 \\
\hline & \multicolumn{3}{|c|}{$\begin{array}{l}\text {-- Improved tall fescue -- } \\
\text { grass clover dead }\end{array}$} & \multicolumn{3}{|c|}{$\begin{array}{c}\text {-- Improved chicory -- } \\
\text { grass clover/ dead } \\
\text { chicory }\end{array}$} \\
\hline March 97 & 72 & 8 & 20 & 0 & 91 & 5 \\
\hline November 97 & 57 & 14 & 25 & 0 & 67 & 19 \\
\hline March 98 & 80 & 2 & 19 & 0 & 76 & 13 \\
\hline November 98 & 72 & 10 & 2 & 0 & 51 & 5 \\
\hline
\end{tabular}

Table 7 Lamb liveweight performance on two dryland systems at Winchmore.

\begin{tabular}{|c|c|c|c|c|c|c|}
\hline 1997/98 & $\begin{array}{c}\text { Liveweight }(\mathrm{kg}) \\
\text { at weaning } \\
11 / 11 / 97\end{array}$ & $\begin{array}{l}\text { birth } \\
\text { to } \\
\text { weaning }\end{array}$ & $\begin{array}{c}11 / 11 / 97 \\
\text { to } \\
10 / 12 / 97\end{array}$ & $\begin{array}{c}\text { eight chan } \\
10 / 12 / 97 \\
\text { to } \\
5 / 1 / 98\end{array}$ & $\begin{array}{c}\text { e }(\mathrm{g} / \mathrm{d}) \\
\text { post- } \\
\text { weaning }\end{array}$ & $\begin{array}{l}\text { birth } \\
\text { to } \\
5 \text { January }\end{array}$ \\
\hline Control & 26.6 & 284 & 181 & 115 & 150 & 227 \\
\hline Improved & 27.9 & 300 & 325 & 255 & 292 & 300 \\
\hline $\operatorname{LSD}_{0.05}$ & 0.9 & 16 & 86 & 167 & 119 & 60 \\
\hline Significance $^{1}$ & * & * & * & ns & * & * \\
\hline 1998/99 & & & $\begin{array}{c}10 / 11 / 98 \\
\text { to } \\
8 / 12 / 98\end{array}$ & $\begin{array}{c}8 / 12 / 98 \\
\text { to } \\
5 / 1 / 99\end{array}$ & & \\
\hline Contr & 27.8 & 289 & 182 & 85 & 133 & 224 \\
\hline Improved & 29.4 & 312 & 348 & 247 & 298 & 311 \\
\hline $\mathrm{LSD}_{0.05}$ & 0.4 & 8 & 71 & 186 & 88 & 38 \\
\hline Significance & 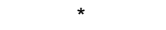 & * & & ns & & \\
\hline
\end{tabular}

${ }^{1} \mathrm{~ns}=$ not significant, ${ }^{*}=\mathrm{P}<0.05$ under sheep grazing on dryland pasture at Winchmore.

\begin{tabular}{|c|c|c|c|c|c|}
\hline \multirow[t]{2}{*}{ Conserved } & \multicolumn{4}{|c|}{ - } & \multirow{2}{*}{ Deficit } \\
\hline & autumn & winter & summer & total & \\
\hline 15.3 & 0.0 & 0.0 & 7.4 & 7.4 & +7.9 \\
\hline 2.9 & 0.0 & 7.3 & 0.0 & 7.3 & 4.4 \\
\hline 10 & - & - & - & 14 & 13 \\
\hline * & & & & ns & ns \\
\hline
\end{tabular}

1998/99

$\begin{array}{lllllll} & 10.7 & 47.9 & 0.0 & 17.1 & 65.1 & 54.4\end{array}$

$\begin{array}{lllllll} & 0.0 & 46.2 & 14.7 & 18.1 & 78.9 & 78.9\end{array}$

Significance ns ns ns

ns $=$ not significant, ${ }^{*}=\mathrm{P}<0.05$ 
Table 8 Lamb carcass production on two dryland systems at Winchmore.

\begin{tabular}{|c|c|c|c|c|c|c|c|}
\hline \multirow[b]{2}{*}{$1997 / 98$} & \multirow{2}{*}{ 11/11/97 } & \multicolumn{5}{|c|}{ 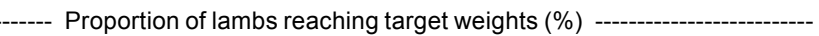 } & \multirow{2}{*}{$\begin{array}{c}\text { Mean age at } \\
\text { drafting (days) }\end{array}$} \\
\hline & & $26 / 11 / 97$ & $10 / 12 / 97$ & $22 / 12 / 97$ & $5 / 1 / 98$ & Total & \\
\hline Control & 1 & 11 & 14 & 13 & 14 & 53 & 111 \\
\hline $\mathrm{LSD}_{0.05}$ & 2 & 11 & 18 & 11 & 11 & 39 & 6 \\
\hline Significance $^{1}$ & * & * & * & ns & ns & * & * \\
\hline $1998 / 99$ & $10 / 11 / 98$ & $24 / 11 / 98$ & $8 / 12 / 98$ & 21/12/98 & $5 / 1 / 99$ & & \\
\hline Control & 7 & 14 & 13 & 8 & 16 & 58 & 109 \\
\hline Improved & 13 & 26 & 40 & 10 & 9 & 98 & 101 \\
\hline $\mathrm{LSD}_{0.05}$ & 1 & 18 & 19 & 15 & 17 & 32 & 4 \\
\hline Significance & $*$ & ns & $*$ & ns & ns & * & * \\
\hline
\end{tabular}

Table 9 Lamb meat production and income for two dryland systems at Winchmore.

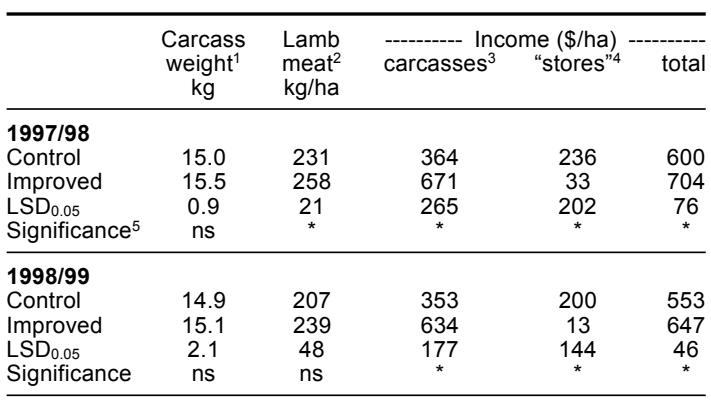

${ }^{1}$ from lambs reaching target weights. ${ }^{2}$ from lambs reaching target weights and stores. ${ }^{3}$ includes meat, pelt and wool from lambs reaching target weights. ${ }^{4}$ includes market value for lambs below target weights. ${ }^{5} \mathrm{~ns}=$ not significant, ${ }^{*}=\mathrm{P}<0.05$

Table 10 Ewe liveweight $(\mathrm{kg})$.

\begin{tabular}{|c|c|c|c|c|c|c|c|}
\hline & $14 / 2 / 97$ & $14 / 3 / 97$ & $21 / 4 / 97$ & $7 / 8 / 97$ & $11 / 11 / 97$ & $16 / 2 / 98$ & \\
\hline $\begin{array}{l}1997 / 98 \\
\text { Control } \\
\text { Improved } \\
\text { LSD }_{0.05} \\
\text { Significance } \\
\end{array}$ & $\begin{array}{l}55 \\
55 \\
0.5 \\
\text { ns }\end{array}$ & $\begin{array}{l}58 \\
58 \\
3.6 \\
\text { ns }\end{array}$ & $\begin{array}{l}60 \\
61 \\
2.9 \\
\text { ns }\end{array}$ & $\begin{array}{l}64 \\
66 \\
4.6 \\
\mathrm{~ns} \\
\end{array}$ & $\begin{array}{l}63 \\
66 \\
2.1 \\
* \\
\end{array}$ & $\begin{array}{l}62 \\
68 \\
3.7 \\
*\end{array}$ & \\
\hline & $26 / 2 / 98$ & $17 / 3 / 98$ & $30 / 4 / 98$ & $4 / 8 / 98$ & $10 / 11 / 98$ & $15 / 2 / 99$ & $15 / 2 / 99$ \\
\hline $\begin{array}{l}\text { 1998/99 } \\
\text { Control } \\
\text { Improved } \\
\text { LSD }_{0.05} \\
\text { Significance }\end{array}$ & $\begin{array}{c}\text { Shorn }^{1} \\
57 \\
57 \\
0.3 \\
\text { ns }\end{array}$ & $\begin{array}{l}60 \\
59 \\
1.4 \\
\mathrm{~ns}\end{array}$ & $\begin{array}{l}63 \\
62 \\
2.3 \\
\text { ns }\end{array}$ & $\begin{array}{l}68 \\
68 \\
3.3 \\
\mathrm{~ns}\end{array}$ & $\begin{array}{l}66 \\
69 \\
3.7 \\
\mathrm{~ns}\end{array}$ & $\begin{array}{l}65 \\
69 \\
6.6 \\
\text { ns }\end{array}$ & $\begin{array}{c}\text { Shorn }{ }^{1} \\
61 \\
65 \\
6.3 \\
\text { ns }\end{array}$ \\
\hline
\end{tabular}

Table 11 Ewe fleece weights (greasy $\mathrm{kg}$ ).

\begin{tabular}{lccc}
\hline & $21 / 7 / 97^{1}$ & $17 / 2 / 98$ & $18 / 2 / 99^{2}$ \\
\hline Control & 3.02 & 2.39 & 3.55 \\
Improved & 3.09 & 2.63 & 3.96 \\
LSD $_{0.05}$ & 0.27 & 0.37 & 0.33 \\
Significance & ns & ns & $*$
\end{tabular}

${ }^{1}$ previously shorn November1996. ${ }^{2}$ previously shorn February 1998

\section{Conclusion}

Herbage growth rates were similar for the grass species used on the two systems but chicory grew more rapidly during the summer. Pasture cover was higher on the Control than Improved systems throughout the year enabling more to be conserved during spring which resulted in a lower feed deficit on the Control than the Improved system.

While the Control system had a higher herbage cover its pastures were of considerably lower quality than those available on the Improved system. This was especially so during late spring and early summer, when lamb requirements were greatest. This improvement in pasture characteristics enhanced lamb liveweight performance on the Improved system during both pre- and post-weaning periods but especially during the latter. This ensured more lambs were drafted from the Improved system and they were drafted earlier. Thus feed availability increased for the remaining lambs thereby enhancing their growth rates. The superior performance from lambs on the Improved system increased total meat production and income from lambs. 
Ewes on the Improved system were heavier at the end of each year and produced more wool than those on the Control system.

The Improved system has shown a means of increasing lamb growth rates thus fulfilling an objective of the sheep industry.

\section{ACKNOWLEDGEMENTS}

The authors gratefully acknowledge the technical assistance of Keith Hewitt, Brenda Stuart and David Saville.

\section{REFERENCES}

Devine, C.E.; Graafhuis, A.E.; Muir, P.D.; Chrystall, B.B. 1993. The effect of growth rate on ultimate $\mathrm{pH}$ on meat quality of lambs. Meat science 35: 63-77.

Fraser, T.J.; Hewson, D.C. 1994. Establishing pastures on east coast downlands by direct drilling. Proceedings of the New Zealand Grassland Association 56: 73-76.

Fraser, T.J.; Rowarth, J.S. 1996. Legumes, herbs or grass for lamb performance. Proceedings of the New Zealand Grassland Association 58: 49-52.

Lynch, P.B. 1960. Measurement of pasture production by frames. pp. 72-73. In: Conduct of field experiments. New Zealand Department of Agriculture Bulletin No. 399.

Rickard, D.S. 1960. The occurrence of agricultural drought at Ashburton, New Zealand. New Zealand journal of agricultural research 3: 431-441. 
